\title{
Collacott Response to Poulton Critique
}

\author{
Martin Collacott
}

$\mathrm{T}$ he critic of my paper, Ronald Poulton, makes clear from the outset his commitment to a refugee determination system that leaves the door as open as possible to the free flow of asylum seekers through our borders. Canada has arguably one of the most generous refugee determination systems in the world in terms of the percentage of successful claimants and the number of asylum seekers we accept, as well as the number of refugees we resettle from abroad. In the circumstances, Poulton's claim that our treatment of foreign nationals is "anything but admirable" obviously misses the mark by a wide margin and is symptomatic of the oft-repeated claims by refugee advocates and particularly lawyers that we are too harsh on asylum seekers as they try to get sympathy for their clients.

As an example of such harsh treatment Poulton cites the case of his client, Manickavasagam Suresh, who was a fundraiser in Canada for the Tamil Tiger terrorist group. Poulton says that Suresh would have been sent back by the Canadian authorities to his native Sri Lanka where he would have been detained, tortured, and in all likelihood summarily executed had his removal order not been stayed by the courts. The facts regarding other Tamil cases, however, suggest otherwise. In January 2006, the Immigration and Refugee Board upheld an order to deport Sri Lankan Jeyaseelam Thuraisingam, a Tamil Tiger supporter and leader of a street gang in Toronto. In response to his lawyer's claim that he would be mistreated if sent back to Sri Lanka, the IRB noted that more than one hundred Sri Lankans had been sent back to their homeland and none had been mistreated as their lawyers claimed they would be. ${ }^{1}$

Yet another area in which the critic provides an example of where he says our system is too harsh is the difficulty we place in the way of Roma from the Czech Republic trying to get to Canada to make refugee claims. In response to my point that no other member state would even consider a claim from a national of the Czech Republic-whether Roma or not-given that that state is a democracy and has a good human rights record and that no other country on earth but Canada grants refugee status to Czech nationals, the best Poulton can manage is to suggest that it is a credit to Canada that we alone have a system that can "cut through the fear of irrational hysteria" and grant refugee status to Roma from the Czech Republic.

In response to this I would refer Poulton to the words of David Anderson, who served on the IRB before returning to politics and being appointed to the Cabinet of Canadian Prime Minister Jean Chrétien. When asked why Canada had such high rates of acceptance for asylum seekers compared to other countries, Anderson observed, "Clearly something is wrong ... either everyone else in the world is wrong or we're out of line and I think it's us. There's too much pressure on our board members to deal with cases, to let people in-the underlying premise is that if someone lied well enough to get here then they'll do well."

In a final effort to throw cold water on the points made in my paper, the critic quotes from statements made in 2005 by former Canadian ambassador and former executive director of the Canadian Immigration Service, James Bissett, relating to the increasing political influence of certain religious and ethnic groups as their numbers grow through immigration. Although Bissett's statements have nothing to do with the refugee system, the critic takes it on himself to imply that such utterances are not only racist in nature but reflect the attitude of people such as myself who dare to raise questions about the effectiveness of our system.

What Poulton is going to have to come to terms with is the realization that the Canadian public is no longer being taken in by the ongoing claims of the refugee lobby that Canada is less than generous when it comes to acceptance of refugees. While the Canadian public continues to support a policy of taking in a reasonable number of genuine refugees, it is increasingly aware of the extent to which the system is being abused by large numbers of individuals who simply want a better life like hundreds of millions of others in less fortunate lands and have the wherewithal to jump the queue and land in Canada as asylum seekers. It is unfortunate that refugee advocates such as Poulton have not to date taken a more balanced approach to the issues and identified areas where the system is not working properly and needs to be improved if widespread abuse is to be avoided. Instead, they 
have helped to make it so dysfunctional that major surgery is now required and the winds of change are no longer blowing to the advantage of the refugee lobby.

\section{Notes}

1. Stewart Bell, "Gang Leader Deported to Sri Lanka," National Post (January 30, 2006).
2. Moira Farrow, "Processing System Branded as 'Corrupt': Refugees: Fake Applicants Accused of Abusing System," Vancouver Sun (March 17, 1992). are credited and the original publication in Refuge: Canada's Journal on Refugees is cited. 